\title{
AS TÉCNICAS DE REPRODUÇÃO HUMANA ASSISTIDA E A PROBLEMÁTICA DA RESPONSABILIDADE CIVIL DOS PAIS
}

Carlos Alexandre Moraes

Coordenador do curso de graduação em Direito do Centro Universitário Cesumar - UNICESUMAR. Mestre em Direito Programa de Mestrado em Direito com ênfase em Direitos da Personalidade do Centro Universitário Cesumar - UNICESUMAR. Doutor em Ciências da Educação - UPAP. Doutorando em Função Social do Direito - FADISP.

Marta Beatriz Tanaka Ferdinandi

Possui graduação em DIREITO pelo Centro Universitário Cesumar - UNICESUMAR (2001). Mestrado em Ciências Jurídicas, pelo Centro Universitário Cesumar - UNICESUMAR (2010). Atualmente é Docente, Advogada e Coordenadora do Núcleo de Prática Jurídica do Centro Universitário Cesumar - UNICESUMAR.

\section{Resumo}

O presente artigo trata da problemática relacionada a responsabilidade civil dos pais quando da utilização das técnicas de reprodução humana assistida. Traçou-se uma discussão acerca dos reflexos dos princípios da parentalidade responsável e da dignidade da pessoa humana na utilização dessas técnicas, delineando uma a uma das mesmas que possam dar ensejo a possíveis danos ao embrião, nascituro ou filho já nascido. Na discussão das técnicas de reprodução humana assistida, delineou-se as permitidas pelo Conselho Federal de Medicina por meio da Resolução n. 2013/2013 e destacou-se a omissão do ordenamento jurídico com relação a regulamentação ao uso dessas técnicas, visto que, o único instrumento normativo que trata do assunto, que é a Lei n. 11.105/2005 não o fez especificamente. Foi apresentado assim, todas as técnicas de reprodução humana assistida que dão ensejo a uma possível potencialização da vulnerabilidade do embrião e as possíveis respostas acerca do status jurídico do embrião que a doutrina tenta traçar. Por fim, discutiu-se as formas de responsabilidade civil, relacionando-a à parentalidade responsável e aos danos que decorrem do não exercício da mesma quando da utilização dessas técnicas.

\section{Palavras-chave}

Reprodução humana assistida; Parentalidade responsável; Embrião; Responsabilidade civil. 


\section{Abstract}

The present study aims to analyze the issues related to the civil responsibility of parents, when using the assisted human reproductions techniques. Drew up a discussion about the reflections of the principles of responsible parenting and of human dignity in the use of those techniques, delineating one by one of them that can cause damages to the embryo, unborn or child already born. Discussing about the assisted human reproduction techniques, it outlined those allowed by the Federal Medical Council through the Resolution $n^{\circ}$ 2013/2013 and stood out the legal system omission related to the regulation of the use of those techniques, since the only legal instrument that deals with it, that is the Law $n^{\circ} 11.105 / 2005$, did not specify about it. Was presented therefore, all human assisted reproduction techniques that give rise to a possible potentiation of vulnerability of the embryo as well as to possibly answers regarding to the legal status of the embryo that the doctrine is trying to trace. Finally, we discussed about the civil responsibility forms, relating it to the responsible parenthood and the damages caused from not using those techniques.

\section{Key words}

Human Assisted Reproductions; Responsible Parenthood; Embryo; Civil Liability.

\section{Introdução}

A parentalidade responsável e a dignidade humana tem sido os princípios que fundamentam o livre exercício do planejamento familiar que é constitucionalmente garantido.

A partir do século XX a evolução das técnicas de reprodução humana assistida trouxe à tona diversas discussóes jurídicas, uma delas trata-se da problemática da responsabilização dos pais na utilização dessas técnicas.

A Constituição Federal de 1988 trouxe o planejamento familiar como livre, com observância dos princípios da parentalidade responsável e da dignidade humana.

As técnicas disponíveis na realização do projeto parental, as que mais se destacam são o diagnóstico genético pré-implantatório, a inseminaçāo artificial, a fertilização in vitro, a maternidade substitutiva e a inseminação post mortem.

Trata-se assim de tema polêmico, mas atualmente é regulamentado somente pelo Conselho Federal de Medicina, por meio da Resolução n. 2.013/2013, que dispóe apenas acerca das normas éticas.

Portanto, há clara omissão do ordenamento jurídico relacionado a regulamentação adequada dessas técnicas, a única lei que trata do assunto, a Lei n. 11.105/2005 não trouxe o tratamento adequado ao tema. 
Outra discussão relacionada a essas situaçóes está relacionado ao status jurídico do embriấo. Foi apresentada as diversas discussóes existentes para na doutrina, apontando a teoria aplicada ao Código Civil e qual seria a forma mais adequada para ser tratado.

Esse trabalho tratará da problemática da responsabilidade civil dentro do âmbito familiar com a utilização das técnicas de reprodução humana assistida, visto que no ordenamento jurídico brasileiro não há qualquer Lei que regulamente essas técnicas, apenas o Conselho Federal de Medicina (Resolução n. 2.013/2013) que normatizou no âmbito administrativo e ético e a Lei n. 11.105/2005 que náo enfrentou o problema e apenas proibiu a manipulação em desacordo com a legislação e a clonagem de embrióes humanos.

Quando da utilização dessas técnicas os pais devem ter uma noção do significado e consequências que a parentalidade responsável gera, inclusive a título de responsabilidade civil.

Quando não há o respaldo da dignidade da pessoa humana ou principalmente da parentalidade responsável na realização do projeto parental, inúmeros conflitos jurídicos passam a existir, como a manipulação genética náo só no intuito de prevenir doenças, mas sim com fins eugênicos, a aplicação da técnica de redução embrionária, desordens que podem envolver a gestação substitutiva, as consequências da inseminação post mortem privando a criança da convivência familiar do de cujus, a destinação dos embriôes excedentários, dentre outras situações.

Diante do emprego dessas técnicas náo se nega a responsabilidade dos pais perante esse ser em desenvolvimento, visto que, as consequências desta refletirá por toda a vida daquele, não somente como criança, mas também quando adolescente, jovem, adulto e idoso.

É justamente nessa seara que surge a discussão da possibilidade de surgir a responsabilidade civil dos pais por essa inobservância, tendo sido o tema delineado a partir dessa problemática.

Por fim, a pesquisa do tema justifica-se por ser relevante tanto para a sociedade como para a comunidade científica, abordando a intervenção do Estado na questão da utilização das técnicas de reprodução humana assistida sem a observância da parentalidade responsável que dê ensejo a responsabilidade civil para esses pais e para sua realização foi utilizado o método teórico, no intuito de fundamentar as posiçóes tomadas acerca do tema.

\section{A Parentalidade Responsável Frente à Utilização das Técnicas de Repro- dução Humana Assistida}

A evolução das técnicas de reprodução humana assistida a partir do século XX trouxe à tona diversas discussóes jurídicas, bem como a possibilidade não só de realização do 
projeto parental por casais com problemas de fecundidade ou esterilidade, mas também por casais homoafetivos ou pessoas solteiras.

Foi a Constituição Federal de 1988 que o planejamento familiar foi colocado como livre, silenciando-se sobre a utilização das técnicas de reprodução assistida na realização desse projeto parental, no entanto, torna-se evidente que, se há a garantia da formação de uma família por métodos naturais, deve-se reconhecer o direito daqueles que optem por procriar utilizando-se dessas técnicas também.

A Lei n. 9.263/2006 autorizou, em seu art. 9º, que, para o exercício do direito ao planejamento familiar, serão oferecidos todos os métodos de reprodução assistida. Enquanto que o Código Civil apenas tratou do tema no art. 1.597, para disciplinar a presunção de paternidade.

Assim pode-se concluir que as técnicas de reprodução humana assistida foram permitidas aos casais com problemas de esterilidade ou fertilidade, aos casais homoafetivos ou às pessoas solteiras, conforme a Resolução n. 2.013/2013 do Conselho Federal de Medicina.

Essas técnicas permitem a fecundação humana, por meio da manipulação de gametas e embriōes, com o objetivo de propiciar o nascimento de um novo ser. ${ }^{1}$

Dentre essas técnicas disponíveis na realização do projeto parental, as de maior destaque são o diagnóstico genético pré-implantatório, a inseminação artificial, a fertilização in vitro, a maternidade substitutiva e a inseminação post mortem.

A inseminação é obtida sem que haja um relacionamento sexual, por meio de recursos mecânicos, com a introdução do sêmen no útero feminino. Podendo ser homóloga, quando o material genético utilizado é do casal, ou seja, pertence ao homem e à mulher que vivem em união estável ou casados, ou heteróloga, que é aquela realizada com o material genético de um terceiro, alheio ao relacionamento do casal. ${ }^{2}$

Já a fertilização in vitro trata-se do método em que a fertilização é realizada em laboratório e ocorre após a transferência do embrião ao útero materno. Deverá ser utilizada quando se houver esgotado o emprego das outras técnicas, visto que é mais invasiva que as demais. ${ }^{3}$

Trata-se assim de tema polêmico, pois interfere diretamente no processo natural da pessoa, desafiando o legislador a reformular conceitos jurídicos já existentes. ${ }^{4}$

\footnotetext{
1 SÁ; NAVES, 2009, p. 110.

2 SILVA, 2002, p. 54.

3 SÁ; NAVES, 2009, p. 111.

4 ROSA; CARDIN, 2012.
} 
Atualmente o emprego dessas técnicas é regulamentado somente pelo Conselho $\mathrm{Fe}$ deral de Medicina, por meio da Resolução n. 2.013/2013, que dispóe apenas acerca das normas éticas, limitando somente no campo ético essas questôes.

Essa Resolução permite que essas técnicas sejam utilizadas desde que haja efetiva probabilidade de sucesso, não trazendo risco grave de saúde para a paciente ou o possível descendente, observando para essas mulheres a idade máxima de 50 anos para a gestação oriunda de reprodução assistida. ${ }^{5}$

Com a finalidade de resguardar saúde da mulher que se submete a essas técnicas o Conselho Federal de Medicina também limita o número de oócitos e embriōes a serem transferidos para a receptora que não poderá ser superior a quatro, variando de acordo com a idade da mulher. ${ }^{6}$

Ainda a Resolução traz que deverá existir o consentimento informado para todos os pacientes submetidos às técnicas de reprodução humana assistida, devendo também o médico trazer todas as informaçóes detalhadamente das circunstâncias abrangidas, atingindo dados de caráter biológico, jurídico, ético e econômico. ${ }^{7}$

Destarte, a infertilidade humana é considerada um problema de saúde, assim, os profissionais da saúde que estiverem realizando esses procedimentos devem ter o cuidado de além de utilizarem um contrato de prestação de serviços que seja adequadamente elaborado, também ter o consentimento informado do paciente, visto que trata-se de uma exigência da própria resolução.

\section{5 "I - PRINCÍPIOS GERAIS}

(...) 2 - As técnicas de RA podem ser utilizadas desde que exista probabilidade efetiva de sucesso e não se incorra em risco grave de saúde para a paciente ou o possível descendente, e a idade máxima das candidatas à gestação de RA é de 50 anos". (BRASIL. Resolução 2.013/2013 do Conselho Federal de Medicina. Disponível em: http://portal.cfm. org.br/images PDF/resoluocfm\%202013.2013.pdf. Acesso em: 06 set. 2014).

\section{6 "I - PRINCÍPIOS GERAIS}

(...)6 - O número máximo de oócitos e embriôes a serem transferidos para a receptora não pode ser superior a quatro. Quanto ao número de embrióes a serem transferidos faz-se as seguintes recomendaçóes: a) mulheres com até 35 anos: até 2 embriōes; b) mulheres entre 36 e 39 anos: até 3 embrióes; c) mulheres entre 40 e 50 anos: até 4 embriōes; d) nas situaçóes de doação de óvulos e embriōes, considera-se a idade da doadora no momento da coleta dos óvulos". (BRASIL. Resolução 2.013/2013 do Conselho Federal de Medicina. Disponível em: http://portal.cfm. org.br/images PDF/resoluocfm\%202013.2013.pdf. Acesso em: 06 set. 2014).

7 "3 - O consentimento informado será obrigatório para todos os pacientes submetidos às técnicas de reprodução assistida. Os aspectos médicos envolvendo a totalidade das circunstâncias da aplicação de uma técnica de RA serão detalhadamente expostos, bem como os resultados obtidos naquela unidade de tratamento com a técnica proposta. As informaçôes devem também atingir dados de caráter biológico, jurídico, ético e econômico. O documento de consentimento informado será elaborado em formulário especial e estará completo com a concordância, por escrito, das pessoas a serem submetidas às técnicas de reprodução assistida." (BRASIL. Resolução 2.013/2013 do Conselho Federal de Medicina. Disponível em: http://portal.cfm. org.br/images PDF/resoluocfm\%202013.2013.pdf. Acesso em: 06 set. 2014). 
Esse consentimento informado irá legitimar o emprego das técnicas, sendo indispensável para a prestação desse serviço, devendo o médico informar todos os possíveis resultados ou não de sua utilização. Assim pode-se afirmar que o consentimento informado é a concordância na aceitação dos serviços a serem prestados pelo profissional de saúde em troca do pagamento do paciente ou responsável, devendo estar esse informado de forma clara e objetiva do que está consentindo. ${ }^{8}$

E mais ainda, trata-se do assentimento para o próprio procedimento, representando o direito do paciente ao respeito à sua integridade pessoal, bem como a disposição de seu corpo de acordo com os bons costumes e a moral. ${ }^{9}$

O grande problema apresentado ao consentimento informado ocorre na medida que questiona-se sua validade quando é utilizado como por exemplo, para a escolha de características genéticas para o filho, escolha do sexo do bebê, para evitar a transmissão de doenças geneticamente transmissíveis, dentre outras?

Nesse sentido, defende-se que do ponto de vista ético na utilização das técnicas de reprodução humana assistida é necessária uma regulamentação visto que nem sempre essas observam uma autonomia responsável, com determinada vigilância a fim de garantir e respeitar os direitos fundamentais das pessoas envolvidas no procedimento.

Ademais, apesar de serem proibidas pela resolução do Conselho Federal de Medicina as práticas de eugenia, de redução embrionária ou de sexagem, comumente se ouve notícias acerca da realização dessas hipóteses visto que não há uma lei que regulamente tais circunstâncias, o que contraria totalmente o princípio da dignidade da pessoa humana. ${ }^{10}$

Com relação aos embrióes excedentes a Resolução n. 2.013/2013 do Conselho Federal de Medicina estabeleceu que os embrióes criopreservados com mais de 5 (cinco) anos poderão ser descartados se essa for a vontade dos pacientes, e não apenas para pesquisas de células-tronco, conforme previsto na Lei de Biossegurança.

Já o diagnóstico genético pré-implantatório é autorizado pela Resolução n. 2.013/2013 do Conselho Federal de Medicina, desde que seja detectado doenças hereditárias no casal, impedindo assim a transmissão dessas para o filho e também em caso de seleção de tipagem do sistema HLA do embrião para seleção de HLA compatíveis com um filho do casal afetado por alguma doença cujo o tratamento efetivo por meio do

8 ROBERTO, 2008, p. $87-88$.

9 ROBERTO, 2008, p. 87-88.

10 “4 - As técnicas de RA não podem ser aplicadas com a intenção de selecionar o sexo (presença ou ausência de cromossomo Y) ou qualquer outra característica biológica do futuro filho, exceto quando se trate de evitar doenças ligadas ao sexo do filho que venha a nascer." (BRASIL. Resolução 2.013/2013 do Conselho Federal de Medicina. Disponível em: http://portal.cfm. org.br/images PDF/resoluocfm\%202013.2013. pdf. Acesso em: 06 set. 2014). 
transplante de células-tronco ou órgão, o que é conhecido como "bebê-medicamento", "bebê-doutor", "bebê-salvador" ou "bebê de dupla esperança".

O bebê medicamento é uma das inovaçôes trazidas pelo Conselho Federal de Medicina e merece destaque, visto que permite inclusive a transferência de células do bebê para o irmão mais velho que tenha doença genética grave. Apesar de haver essa seleção genética, ainda é proibido escolher o sexo do bebê, exceto quando a seleção envolva doenças relacionadas ao sexo. ${ }^{11}$

Assim pode-se citar como exemplo o caso de um casal que tem um filho que precisa de transplante de medula, procurando a ajuda dessas técnicas poderá produzir, por meio da reprodução humana assistida, um filho geneticamente compatível com o primeiro para efeito do transplante. Portanto, esse filho concebido com a intenção de salvar um irmão mais velho que tem uma doença genética grave faz a coleta de material genético já após o parto para um possível transplante se o recém-nascido for compatível com o doente, a simples presença de uma hemoglobina funcional pode acarretar a cura total dessa doença. ${ }^{12}$

Trata-se de uma questão polêmica e muito atual, mas muito pouco discutida no Brasil, a Maria Clara, foi a primeira bebê medicamento da América Latina que "gerada e selecionada in vitro para ser compatível geneticamente e, portanto, doadora para a sua irmã mais velha, Maria Vitória”"13, trazendo ao país uma série de questionamentos relacionados a dignidade de ser que foi gestado nessa situação.

Trata-se de uma resposta que deverá ser buscada na ética, visto que bem preconiza o princípio da dignidade humana em que o ser humano tem que ter um fim em si mesmo.

Diagnóstico genético pré-implantatório trata-se de uma técnica que permite a seleção e análise genética dos embrióes com a escolha daquele que deverá ser implantado e a possibilidade de detectar possíveis anomalias, ou a certeza de que os embrióes são geneticamente normais ${ }^{14}$.

A possibilidade de poder escolher o sexo ou as características físicas de um filho traz a tona a possibilidade de realização da eugenia e por isso faz-se imprescindível a limitação e o controle normativo dessas técnicas.

Identifica-se duas formas de eugenia, a negativa que é aquela empregada no sentido de eliminar características indesejáveis, evitando sua transmissão, evitando-se o nascimento de indivíduos com genes considerados inferiores, e a eugenia positiva, na qual busca

11 BRASIL. Resolução n. 2013/2013do Conselho Federal de Medicina. Disponível em: http://portal.cfm. org. br/images PDF/resoluocfm\%202013.2013.pdf. Acesso em: 06 set. 2014

12 MAROJA; LAINÉ, Agnès, 2014.

13 GARCIA, Lenise, 2014.

14 ROBERTO, 2008, p. 154. 
promover que características desejáveis (boas ou más) sejam transferidas, objetivando favorecer o nascimento de indivíduos com determinados problemas. ${ }^{15}$

Portanto, o diagnóstico não poderá ter outro fim que não o de impedir doenças hereditárias e a possibilidade do bebê medicamento, ou seja, apenas para fins terapêuticos, jamais eugênicos fundamentados em valores racistas, sexistas, étnicos, dentre outros ${ }^{16}$.

Tiago Figo Freitas adverte que nem sempre este procedimento é utilizado de forma lícita, ou seja, com o intuito de identificar os riscos para a saúde da mulher grávida ou a normalidade da criança que está por vir. ${ }^{17}$

Com relação a maternidade substitutiva está autorizada pela Resolução n. 2.013/2013, devendo ser utilizada sempre que a mulher tiver algum problema médico que impeça ou contraindique a gestação na doadora genética ou em caso de ser um casal homoafetivo. $^{18}$

As doadoras temporárias do útero devem pertencer à família de um dos cônjuges ou companheiros, com parentesco consanguíneo até o quarto grau (primeiro grau - mãe; 8 segundo grau - irmâ/avó; terceiro grau - tia; quarto grau - prima) e com a idade de no máximo 50 anos. Frise-se que não deverá ter fim lucrativo e a resolução inovou quando trouxe a garantia do registro civil da criança pelos pais genéticos, com a documentaçáo a ser providenciada durante a gravidez e também, a exigência de que se a doadora temporária do útero for casada ou viver em união estável, deverá necessariamente apresentar, por escrito, a aprovação do cônjuge ou companheiro. ${ }^{19}$

Também tem-se a redução embrionária, outro procedimento que a Resolução n. 2.013/2013 do Conselho Federal de Medicina proíbe os profissionais da saúde de realizarem, no entanto, que é utilizado frequentemente já que essa proibição fica restrito a seara ética dos médicos.

Trata-se a redução embrionária uma prática invasiva realizada no final do primeiro trimestre, em que se faz uma punção do tórax do feto com a infusão de cloreto de potássio, resultando na parada cardíaca deste. ${ }^{20}$

Há na realização dessa prática um tremendo relativismo ético, em decorrência de que as práticas de congelamento, de redução embrionária, bem como as pesquisas com embriôes, apesar de terem como resultado a destruição destes, não são penalizadas. Aqui

15 VIEIRA, 2009, p. 47.

16 ROSA; CARDIN, 2012.

17 FIGO FREITAS, 2010, p. 142-143.

18 BRASIL. Resolução 2.013/2013 do Conselho Federal de Medicina. Disponível em: http://portal.cfm. org. br/images PDF/resoluocfm\%202013.2013.pdf. Acesso em: 06 set. 2014.

19 BRASIL. Resolução 2.013/2013 do Conselho Federal de Medicina. Disponível em: http://portal.cfm. org. br/images PDF/resoluocfm\%202013.2013.pdf. Acesso em: 06 set. 2014.

20 FARIA; PETTERSEN, 2010, p. 374. 
também faz-se necessário a regulamentação de tal prática para casos extremos, visto que, a redução indiscriminada atenta quanto à vida dos fetos. ${ }^{21}$

Outro procedimento é a inseminação post mortem, realizada após a morte de um dos genitores que é permitido pela Resolução n. 2.013/2013 do Conselho Federal de Medicina, desde que haja autorização prévia e específica do(a) falecido(a) para a utilização do material biológico criopreservado, e observe a legislação vigente. ${ }^{22}$

Destarte, trata-se de uma técnica que pode gerar inúmeros conflitos na área jurídica, pois atinge os direitos personalíssimos dos embrióes envolvidos, em decorrência das consequências pessoais e patrimoniais a que ficam submetidos. ${ }^{23}$

Portanto, a mulher precisará do consentimento do esposo ou do companheiro, tanto na reprodução assistida homóloga quanto na heteróloga para realizar tal procedimento. ${ }^{24}$

Para Sílvio de Salvo Venosa, o Código Civil é omisso, pois "não autoriza nem regulamenta a reprodução assistida, mas apenas constata lacunosamente a existência da problemática e procura dar solução ao aspecto da paternidade.” 25

Nesse sentido, quando a inseminação for realizada sem o consentimento expresso do marido ou do companheiro, deve ser reconhecido apenas o vínculo de filiação, não gerando direitos de ordem patrimonial, como os direitos sucessórios ${ }^{26}$, essa medida deve ser tomada para que não se gere conflitos de nível patrimonial entre os herdeiros já nascidos a época da morte e os que possam vir a nascer depois por puro interesse patrimonial do pai ou mãe sobrevivente.

Não obstante, tal posicionamento deve ser rechaçado, porque com base no princípio da dignidade da pessoa humana e da igualdade entre os filhos, os nascidos por reprodução assistida tem o direito à filiação e à sucessão, como os demais filhos o problema é qual herança teria, se ao tempo da inseminação já não houvesse mais bens.

A proteção do embriáo frente a inseminação post mortem, deve ser avaliada pois os direitos à filiação, ao convívio familiar, e a dignidade do ser em desenvolvimento deve preponderar sob o direito de procriar da pessoa que a realize.

Logo, na inseminação post mortem é necessário uma lei no sentido de fixar lapso temporal para a transferência desses embrióes após a morte, pois enquanto isso não ocorre o direito sucessório desse embriāo está condicionado ao nascimento até dois anos da abertura

21 Nesse sentido: CARDIN; ROSA, 2013, p. 192; ROSA; CARDIN, 2012.

22 BRASIL. Resolução 2.013/2013 do Conselho Federal de Medicina. Disponível em: http://portal.cfm. org. br/images PDF/resoluocfm\%202013.2013.pdf. Acesso em: 06 set. 2013.

23 ROSA; CARDIN, 2012.

24 CARDIN; WINCKLER, 2012, p. 66.

25 VENOSA, 2005, p. 256.

26 Nesse sentido, DELGADO, 2004. 
da sucessão, enquanto que o direito a herança, no prazo de 10 anos por meio da ação de petição de herança, trata-se de umas das problemáticas mais complexas relacionadas as técnicas de reprodução humana assistida.

Pode-se afirmar que diante da utilização de todas essas técnicas apresentadas acima, as soluçóes para tais conflitos geram muitas controvérsias entre os doutrinadores, porque não há uma legislação específica no ordenamento jurídico brasileiro acerca do tema. Somente a Resolução do Conselho Federal de Medicina n. 2.013/2013 que disciplina a matéria com normas de ordem administrativa e ética, sancionando apenas os profissionais da área da saúde. Há também a Lei de Biossegurança, contudo só tratou da destinação dos embriôes excedentários, do lapso temporal de criopreservação e da proibição da clonagem humana e manipulação genética.

Por fim, ressalta-se que o exercício da parentalidade responsável é imprescindível quando da utilização das técnicas de reprodução humana assistida para que não cause qualquer consequência que possa ser maléfica em decorrência de seu uso à criança que está a ser gerada, podendo gerar até mesmo responsabilidades para esses pais.

\section{Embrião: Sujeito ou Objeto de Direito?}

Quando se trata de reprodução humana assistida não se pode esquecer que as maiores discussóes recaem sobre o status jurídico do embriāo in vitro, visto que o ordenamento jurídico não dispóe nada sobre ele, ou seja, o deixa a cargo do Conselho Federal de Medicina, sendo que a Lei de Biossegurança somente dispóe sobre as condutas acima delineadas.

Há diante da humanidade uma tecnologia que promete intervir nos genes humanos buscando a criação de seres perfeitos que permitirá prolongar a vida desses cada vez mais. ${ }^{27}$ Com essas intervençóes, surgem questóes controversas e dentre elas, de quais são e devem ser os limites para a manipulação do embriâo humano e por qual motivo deve ser protegido, embora ainda náo seja considerado um sujeito de direito. ${ }^{28}$

Segundo Francisco Amaral sujeito de direito pode ser considerado aquele que participa de uma relação jurídica, sendo, portanto, titular de direitos e deveres. Já quando se trata de personalidade jurídica sabe-se que é qualidade inerente ao ser humano, que o torna titular de direitos e deveres. ${ }^{29}$

Grande complexidade também reside na discussão do início da vida humana, mas as dificuldades aumentaram com o embrião in vitro ${ }^{30}$, pois estes são concebidos e

27 SÁ; NAVES, 2009, p.159.

28 CARDIN; ROSA, 2014.

29 AMARAL, 1998, p. 205.

30 ROMEO CASABONA; QUEIROZ, 2005, p.249. 
mantidos em laboratório, não podendo ser classificados como nascituros, muito menos prole eventual.

Portanto, o embrião não pode ser confundido com a pessoa, o nascituro ou até mesmo com a prole eventual, pois apesar de possuírem a mesma natureza, estão em estados de desenvolvimento diferenciados, devendo receber uma proteção, mas diferenciada.

Quando se fala de pessoa, tem-se a dimensão de ser o ser humano, dotado de corpo, mente e espírito, diferenciando-se dos demais seres vivos por possuir racionalidade, poder de livre arbítrio e capacidade de se organizar por meio de normas. ${ }^{31}$

Ao se tratar de nascituro considera-se aquele que não nasceu, mas que já foi concebido, sendo sujeito de direito, visto que o próprio Código Civil dispóe que deve ser protegido, sendo encontrado no ordenamento até alguns direitos em que podem ser titulares.

Atente-se ao fato de que o nascituro não é dotado de personalidade jurídica ${ }^{32}$, apenas possui uma expectativa de vida humana, a lei não deixa de observar esse aspecto, assegurando-lhe previamente eventuais direitos.

Já a prole eventual, considerada aquela que ainda está por nascer, não foi concebida, por isso não pode ter a mesma tutela que o embrião. É um instituto do direito brasileiro e que de acordo com o inciso I do art. 1.799 do Código Civil são considerados os filhos, ainda náo concebidos, de pessoas indicadas pelo testador, que estejam vivas à época da abertura da sucessão.

Com isso surge uma nova questão ao ordenamento jurídico, acrescentando a discussão referente ao status jurídico dos embrióes in vitro.

Maria Helena Diniz entende que "a vida humana é amparada juridicamente desde o momento da singamia, ou seja, da fecundação natural ou artificial do óvulo pelo espermatozoide". ${ }^{33}$

Ainda afirma que o embrião tem todos os atributos da espécie humana, merece a proteção de sua vida, integridade física e dignidade (CF, arts. $1^{\circ}$, III, e $5^{\circ}$, III), imagem cientifica (DNA) não se admitindo qualquer investigação experimental. ${ }^{34}$

Wanderlei de Paula Barreto diferencia o embriāo in anima nobile do in vitro. O primeiro é entendido como aquele que está implantado dentro do útero materno, em fase de gestação, logo estes poderiam ser considerados como pessoa dependendo da teoria do

31 BARRETO, 2004, p. 3.

32 O Código Civil em seu art. $2^{\circ}$ traz que, a pessoa adquire a personalidade jurídica com seu nascimento com vida, mas a lei tutela os direitos do nascituro desde a concepção. Portanto, apesar de não ter personalidade jurídica, o ordenamento jurídico assegura os direitos do nascituro.

33 DINIZ, 2010, p.22.

34 DINIZ, 2010, p.508. 
início da vida que for adotada (natalista, concepcionista, da personalidade condicional, dentre outras). Já o embrião in vitro, considera-se aquele que foi criado em laboratório e pode ser implantado no útero depois, este não pode ser considerado como pessoa, pois seu desenvolvimento só ocorrerá quando houver a implantação, ou seja, uma vida náo imediata. ${ }^{35}$

Já para Silmara Juny A. Chinellato Almeida, os embrióes congelados não podem ter a mesma condição do nascituro, o que lhes seria atribuído assim que houvesse a implantação no útero, com o início da gravidez. Somente a partir desse momento é que existiria um novo ser, sendo que a proteçáo dada ao embriáo in vitro deve ser a de uma pessoa virtual ou in fieri. ${ }^{36}$

Ressalte-se que, as características da continuidade e desenvolvimento do embrião, juntamente com a sua nova informação genética, faz dele uma nova vida humana, ressaltando desta forma, a importância do embrião sobre as demais células do corpo humano. ${ }^{37}$

Quando o ordenamento jurídico reafirma a proteção da vida humana desde a concepção não pressupõe, a atribuição de personalidade jurídica a esse nascituro, pois essa decorre do nascimento com vida. Já ao embriāo, em qualquer fase, deve ser tutelado, mas "não há como considerá-lo detentor de direitos subjetivos, deveres jurídicos, direitos potestativos, sujeição, poderes, ônus ou faculdades". ${ }^{38}$

O Pacto de São José de Costa Rica estabelece em seus dispositivos, diversos direitos fundamentais dos seres humanos, dentre eles o direito à vida. Esse direito deve ser protegido pela lei e se dá desde o momento da concepção, não há no documento qualquer distinção entre vida humana intra ou extrauterina, portanto pode-se concluir que a Constituição Brasileira protege o direito a vida da pessoa e que esse direito começa no momento da concepção. ${ }^{39}$

O direito a vida é prioritário, pois sem ele não seria possível o exercício dos outros direitos fundamentais. ${ }^{40}$ Ele prevalece sobre qualquer outro direito, ou seja, se houver "conflito entre dois direitos, incidirá o princípio do primado do mais relevante". ${ }^{41}$

Portanto, o direito à vida é um direito fundamental, indisponível, porque ninguém pode desfazer-se do direito de continuar a viver, visto ser uma cláusula pétrea do ordenamento jurídico e consiste no maior bem do homem, pois condiciona os demais direitos da personalidade. Sendo assim, deve ser protegido contra tudo e contra todos. ${ }^{42}$

35 BARRETO, 2011.

36 ALMEIDA, 2000, p. 11.

37 ANDORNO, 1998, p. 170.

38 SÁ; NAVES, 2009, p. 125.

39 MEIRELLES; NETO, 2014.

40 GARCIA, Maria. [et. al.], 2010, p. 108.

41 DINIZ, 2010, p. 25.

42 LAGO, Danieli. op. cit. 
No entanto, considera-se que a vida não se restringe apenas a seu sentido biológico de incessante auto-atividade funcional, que é própria das matérias orgânicas, mas sim é constituída por um processo vital instaurado com a concepção e passa por uma série de transformaçóes até se chegar a morte. ${ }^{43}$

Também não se pode esquecer de um princípio basilar do nosso ordenamento jurídico, que é o da dignidade da pessoa humana e que encontra-se dentre os fundamentos do Estado Democrático de Direito, com uma natureza constitucional previsto no inciso III, artigo $1^{\circ}$ da Constituição Federal e esta inserido no núcleo dos direitos fundamentais, a fim de proteger os direitos humanos contra qualquer tipo de violação ${ }^{44}$.

Segundo Emmanuel Kant, "a dignidade da pessoa é considerada como fim e não como meio, repudiando toda e qualquer coisificação e instrumentalização do ser humano". 45

Por esse princípio tem-se a convicção de que todas as pessoas, indistintamente, sejam dignas e, portanto, tratadas com igual respeito e consideração tanto entre si quanto pelo Estado ${ }^{46}$, e não se distingue as fases de desenvolvimento em que a vida humana se encontra.

Existem atualmente diversas teorias que tentam explicar o início da proteção jurídica à vida humana, delas três teorias são mais relevantes em apontar, sendo elas: teoria natalista, na qual o nascituro só adquire personalidade após o nascimento com vida; teoria da personalidade condicional, em que os direitos do nascituro estão subordinados a uma condiçáo, sendo esta o nascimento com vida, portanto, a personalidade começa com a concepçáo, mas o exercício de alguns direitos estáo condicionados a seu nascimento com vida; e, por fim, a teoria concepcionista, que considera que o nascituro adquire a capacidade de direitos no momento de sua concepção ${ }^{47}$.

Já o Código Civil brasileiro adotou a teoria natalista, estabelecendo em seu artigo $2^{\circ}$, que a personalidade da pessoa começa do nascimento com vida, pondo a salvo desde a concepção os direitos do nascituro ${ }^{48}$.

Destarte, o art. 5 da Lei n. 11.105/2005, única lei que trata sobre o embriâo, foi objeto de uma ação de inconstitucionalidade e dispõe que será permitida a utilização desses embrióes excedentários com intuito terapêutico e de pesquisa desde que sejam

43 RIBAS, 2014.

44 SÁ; NAVES, 2009, p.56.

45 VASCONCELOS, 2006, p.113.

46 CHUEIRI, 2009, p.43.

47 ALMEIDA apud ROMEO CASABONA; QUEIROZ, 2005, p.250.

48 BRASIL, Código Civil brasileiro. Disponível em: Acesso em: http://www.planalto.gov.br/ccivil_03/ leis/2002/110406.htm. Acesso em: 29 nov. 2014. 
considerados inviáveis, ou estejam congelados há três anos ou mais da data de publicação da lei, com o consentimento dos genitores sem fins lucrativos.

Em regra, esse lapso temporal de três anos é fundamentado no sentido que nesse prazo o casal terá tempo razoável para decidir sobre seu projeto parental, ou seja, a concretização do seu planejamento familiar.

Mas é justamente na destinação para as pesquisas científicas que a vulnerabilidade do embrião se potencializa, visto que o ordenamento jurídico não contribuiu na imposição de limites claros, tornando-se controversos.

Com relação aos embriôes inviáveis considera-se aqueles sem potencialidade para o desenvolvimento celular. Apenas 30\% a 40\% dos embrióes criopreservados excedentes possuem um bom potencial reprodutivo, já os de baixo potencial, que representam menos de $10 \%$, são fruto de tratamento em que a paciente não engravidou. Portanto, os primeiros podem ser doados a casais com dificuldades de reprodução e sem condições de arcar com os custos de um tratamento. ${ }^{49}$ Os últimos, deveram ser encaminhados à pesquisa, com o devido consentimento dos genitores.

O grande problema é que a adoção de embriôes levantam outros conflitos jurídicos, tal como, por exemplo, o direito ao conhecimento da origem genética que é um direito personalíssimo, em face ao direito de sigilo do doador, a possibilidade de existência de impedimentos matrimoniais constantes no art. 1521 do CC a futuros casais, dentre outros.

Outra classificação de embriôes inviáveis é de que podem existir duas espécies, àqueles que não têm qualidade para implantação, estando muito fragmentados ou pararam de se dividir ou àqueles que têm mutaçôes responsáveis por doenças genéticas, sendo possível detectá-las antes de sua transferência para o útero. ${ }^{50}$

Mas na verdade quem vai detectar essa viabilidade é o próprio médico que realiza o diagnóstico pré-implantacional, ficando novamente a cargo de sua ética a consideração de viabilidade desse embrião.

Portanto, apesar de os embrióes in vitro estarem distantes de ser pessoa concebida pela lei formal, devem ser protegidos da mesma forma que as pessoas e os nascituros são, o mais razoável seria conferir uma tutela particular a este, "desvinculada dos conceitos existentes, mas que impeça, de modo eficaz, sua instrumentalização, dando-lhe enfim, proteção jurídica condizente ${ }^{51}$ " a sua situação.

49 Disponível em: http://www.comciencia.br/noticias/2005/06/celulas_tronco.htm. Acesso em: 12 nov. 2011.

50 ZATZ, 2014.

51 ROMEO CASABONA; QUEIROZ, 2005, p.268. 
Verifica-se então, que o embriāo já implantado é sim titular de direitos, enquanto o embrião in vitro, apesar de não ser um sujeito possuidor de direitos, não se nega a natureza humana, ou seja, devendo sim receber uma tutela, pois as próprias técnicas de manipulação genética o colocam em situação de vulnerável.

Desta forma, o próprio ato de viver nos coloca em situação de vulnerabilidade, podendo ser potencializada de acordo com a situação ou relação em que se encontra.

Assim, essa vulnerabilidade está presente em todos os seres vivos, pois estar vivo implica estar suscetível a um perigo ou a um eventual dano. ${ }^{52}$

A situação do embriáo in vitro se coloca em um papel de vulnerabilidade corrente, pois trata-se de um ser que não possui capacidade de defesa ou ao menos de expressar sua vontade, é naturalmente frágil, pois seu desenvolvimento dependerá de uma série de fatores externos.

Por fim, o maior problema da reprodução humana assistida esteja no sentido de que permite que as pessoas que optem por realizar o projeto parental por meio delas, façam escolhas que possam influenciar a vida desse embriāo ao longo de todas as fases de sua vida.

\section{A Problemática da Responsabilidade Civil dos Pais Decorrente da Utiliza- ção das Técnicas de Reprodução Humana Assistida}

Tem-se a dimensão que a parentalidade responsável trata-se da obrigaçáo que os pais têm de prover a assistência moral, afetiva, intelectual, material, espiritual e sexual aos filhos. ${ }^{53}$

Por isso o planejamento familiar é livre desde que observados a parentalidade responsável e a dignidade da pessoa humana, pois exige que o casal ou a pessoa esteja consciente do ato de planejar a família, trazendo aos consortes uma responsabilidade social. ${ }^{54}$

O princípio da parentalidade responsável se relaciona ao fato de que a responsabilidade dos pais com esta criança começa na concepção, estendendo-se até que seja necessário e justificável o acompanhamento dos filhos, efetivando-se desta forma, a garantia fundamental prevista no art. 227 da Constituição Federal atual. ${ }^{55}$

É por isso que a parentalidade responsável deve ser observada juntamente com o princípio da dignidade humana, afinal essa responsabilidade deverá ser ressalvada tanto

52 GARRAFA; PESSINI, 2003, p. 72.

53 ROSA; CARDIN, 2012.

54 REIS, 2008. p. 423.

55 PIRES, Thiago José Teixeira. Princípio da Paternidade Responsável. [2001?]. Disponível em: http://www. apmp.com.br/juridico/artigos/docs/2001/1206_andreluiznogueiradacunha>. Acesso em 02 set. 2007. 
na formação, quanto na manutenção da família, e traduzida na busca de um ambiente propício para que seus membros possam se desenvolver saudavelmente e se realizar enquanto pessoa. ${ }^{56}$

Ressalta-se que, busca-se também o alcance da parentalidade responsável por uma ótica do cuidado, que caracteriza-se ontologicamente e em sua concepção filosófica como a existência do próprio homem, constituindo assim um dos valores jurídicos que legitima o estabelecimento de direitos e deveres inerentes às relaçóes de natureza familiar. ${ }^{57}$

Ao se falar em responsabilidade civil remonta-se ao princípio de direito segundo o qual non nemine laedere, onde ninguém possui o direito de lesar outrem, sob pena de ter o dever de ressarcir o prejuízo causado. ${ }^{58}$

Responsabilidade, em sentido gramatical significa "obrigação de responder pelos seus atos ou pelos de outrem" ${ }^{59}$, ou seja, "res.pon.sa.bi.li.da.de s.f (responsável + i + dade) 1. Qualidade de responsável. 2. Dir Dever jurídico de responder pelos próprios atos e os de outrem, sempre que estes atos violem os direitos de terceiros, protegidos por lei, e de reparar os danos causados [...]". ${ }^{60}$

Não obstante, para uma acepção jurídica da palavra verifica-se que:

1 - Passividade, à sanção penal ou civil, da pessoa que, com dolo ou culpa, viola a regra social obrigatória. 2 - Dever jurídico, imposto a cada um, de responder por ação ou omissão imputável, que importem na lesão do direito de outrem, protegido pela lei [...]. ${ }^{61}$

Assim, quando uma conduta que decorre de um ato unilateral constitui-se em uma violação a um dever moral e jurídico, produzindo no sujeito passivo um prejuízo, surge o dever de indenizar. Destarte, a responsabilidade civil representa sempre o dever de computar ao outro o dano que lhe foi causado. ${ }^{62}$

Maria Helena Diniz traz que a responsabilidade civil é na verdade a aplicação de medidas que obrigam uma pessoa a reparar dano moral ou patrimonial causado a terceiros, em razão de ato por ela praticado, por pessoa por quem ela responde. ${ }^{63}$

São várias as teorias apresentadas, pode-se conceituar a responsabilidade civil como a obrigação legal que uma pessoa tem de reparar o dano causado ilicitamente a outrem. ${ }^{64}$

56 ROSA; CARDIN, 2012.

57 BARBOZA, 2011, p. 86.

58 SOUZA, 2002, p. 21.

59 BUENO, 1991. p. 587.

60 MICHAELIS, 1998. p. 1.829.

61 NUNES, 1994. p. 750.

62 ALSINA, 1997, p. 71-73.

63 DINIZ, 2002. p. 34.

64 MORAES, 2008. 
Define-se a responsabilidade civil contratual como aquela que decorre de um negócio jurídico; ou extracontratual quando o ato ou a omissão de uma pessoa extrapola a conduta normal do homem diligente, lesando o direito de outrem. ${ }^{65}$

É necessária a verificação de quatro elementos para a configuração da responsabilidade civil: a prática de um ato ilícito, a existência ou náo de culpa, o nexo causal, e, por fim, a comprovação do dano. ${ }^{66}$

Para Jorge Bustamante Alsina, o conceito de ilicitude é toda conduta antijurídica, ou seja, qualquer ação ou omissão contrária ao ordenamento jurídico considerado em sua totalidade ${ }^{67}$.

Para Ruy Stoco, "o elemento primário de todo ilícito é uma conduta humana e voluntária no mundo exterior". ${ }^{68}$ Portanto, a conduta humana é elemento essencial para caracterização da responsabilidade civil. Porém, não é a única conduta, pois os danos causados por animais são de responsabilidade de seus donos ou da pessoa que detém a guarda. ${ }^{69}$

Pelo Código Civil brasileiro em seu art. 186: "aquele que, por ação ou omissão voluntária, negligência ou imprudência, violar direito e causar dano a outrem, ainda que exclusivamente moral, comete ato ilícito".

Portanto, uma vez praticado o ato ilícito, deve-se analisar se a ação ou omissão do agente foi resultado de uma vontade livre e consciente (dolo) ou se decorreu de negligência, imprudência ou imperícia (culpa). ${ }^{70}$

Geralmente a responsabilidade civil é subjetiva, ou seja, depende da verificação da culpa ou dolo do agente. Contudo, excepcionalmente, a responsabilidade pode ser aferida objetivamente, isto é, independentemente de culpa. Isto se aplica nas hipóteses definidas em lei, como no art. 927, $\$$ do Código Civil, e art. 12, 14, 18 e 20 do Código de Defesa do Consumidor (Lei n. 8.078/1990). ${ }^{71}$

Destarte, o nexo de causalidade ou a relação causal é, por sua vez, um elemento material da responsabilidade civil, porque constitui o vínculo externo entre a ação ou omissão do agente e o dano sofrido pela pessoa. De acordo com a teoria da causalidade adequada, apenas será causa de um evento danoso se for possível prever que determinada conduta produzirá tal resultado, ou seja, deve haver uma relação de adequação entre a causa e a consequência ${ }^{72}$.

65 LIMA, 1988, p 56.

66 Nesse mesmo sentido: SILVA, 2002, p. 25; MORAES, 2008.

67 ALSINA, 1997 p. 74.

68 STOCO, 1999. p. 64.

69 MORAES, 2008.

70 SOUZA, 2002, p. 25.

71 ROSA; MOCHI, 2012, p. 150-177.

72 GESUALDI, 2000, p. 72-76. 
Assim, para que haja a responsabilização civil é necessário que ocorra um dano, ou seja, a ação ou omissáo do agente deve ocasionar uma lesão sobre o patrimônio moral ou material da vítima ${ }^{73}$.

Atualmente o afeto passou a ser além de fundador e justificador de uma entidade familiar, também o alicerce para nortear as relaçóes familiares, ou seja, trata-se de um princípio com valor jurídico que irá direcionar as relaçóes jurídicas do direito e família.

Desde que a pessoa passou a ser o centro da tutela estatal, com a despatrimonialização do direito civil, passou-se a uma valorização da família como um lugar de afeto, privilegiado, onde a cumplicidade e a solidariedade contribuem para o crescimento pessoal de cada um de seus membros.

De tal modo afirma Maria Berenice Dias:

Cada vez mais se valoriza as funçôes afetivas da família. Basta atentar a toda uma nova terminologia: filiação socioafetiva, dano afetivo etc. E, na medida em que se acentuam as relaçóes de sentimentos entre os seus membros a família se transforma. Foi o afeto e o princípio da afetividade que trazem legitimidade a todas as formas de família. Portanto, hoje, todas as relações e formaçóes da família são legítimas. ${ }^{74}$

Sendo que, o que une a família não é um afeto qualquer, se assim fosse, uma simples amizade seria família, ainda que sem convívio, e o conceito de família seria estendido com inadmissível elasticidade. ${ }^{75}$

$\mathrm{O}$ afeto familiar frise-se, é aquele que une intimamente duas ou mais pessoas para uma vida em comum. Sendo reconhecido como princípio, mas sua força é ainda maior do que se fosse positivado, pois são os princípios que traz a correta interpretação da norma jurídica, são a bússola que conduz o legislador e o intérprete da norma. ${ }^{76}$

Dada essa importância do afeto como elemento formador das relaçôes familiares, recentemente tem sido visto na jurisprudência pátria decisões com relação ao abandono afetivo, ou seja, a intervenção do Poder Judiciário na garantia do dever de cuidado paterno para com o filho, sob pena daquele ter que indenizar civilmente esse.

Ainda diverge a doutrina acerca da possibilidade de aplicaçáo das normas de responsabilidade civil e consequentemente do surgimento do dever de indenizar dentro das relações familiares.

73 SILVA, 2002, p. 25.

74 DIAS, 2009, p. 93.

75 BARROS, 2000, p. 8.

76 CARDIN; FROSI, 2010. 
Nota-se claramente a inclinação da jurisprudência em aplicar o art. 5º, V e X da Constituiçãao Federal concomitante com os arts. 186 e 927 do Código Civil que tratam do dano moral às relaçóes familiares.

Acrescenta-se que o novo enfoque constitucional dado à família valorizou o vínculo de afeto e solidariedade entre seus membros, exigindo deles responsabilidades quando da prática de atos que causam dano em detrimento aos outros. ${ }^{77}$

Portanto, a lesão produzida por um membro da família a outro, independente da sua fase de desenvolvimento é maior do que se fosse provocada por um estranho, visto que há uma situação privilegiada daquele frente a este, fundamentando assim, a aplicabilidade da teoria geral da responsabilidade civil, visto a falta de um dispositivo específico acerca do tema. ${ }^{78}$

Segundo Beatriz R. Bíscaro, quando um membro da família lesiona o direito de outro, isto demonstra que a harmonia não existe, e a negação da reparação civil nestes casos estimularia a reiteração da lesão, acelerando o processo de desintegração familiar ${ }^{79}$.

Se a responsabilidade civil deve ser aplicada nas relaçóes familiares, a prática de um ato ilícito neste contexto também pode acarretar a reparação por danos morais, como ensina Arnaldo Marmitt:

No Direito de Família abundam os valores imateriais indenizáveis. É terreno fértil da violência familiar, que por sua força e insuportabilidade já não mais permanece oculta aos olhos dos outros. Com freqüência exsurgem lesóes graves dessa área do Direito. São os prejuízos morais resultantes de vulneração de virtudes da personalidade, dos atributos mais valiosos da pessoa, de sua riqueza interior, de sua paz jurídica, destruídas pelo parente, pelo esposo ou convivente. O patrimônio moral e familiar é algo muito precioso e de grande estimação, visto ser construído com carinho, afeto e sentimento em cada minuto da vida. A ofensa a esses bens superiores gera o dano moral ressarcível. ${ }^{80}$

O princípio da dignidade da pessoa humana, o afeto e o dever de solidariedade devem prevalecer em qualquer entidade familiar. A partir do momento em que tais princípios não forem respeitados, assim como o princípio da proteção integral e do melhor interesse da criança e do adolescente, deve-se responsabilizar os entes familiares que praticam condutas incompatíveis com os princípios acima referidos ${ }^{81}$.

77 CARDIN, 2012, p. 69

78 CARDIN, 2012, p. 69.

79 BÍSCARO, 1999, p. 436.

80 MARMITT, 1999. p. 113.

81 CARDIN, 2012, p. 69. 
Quando os pais violam os direitos assegurados aos seus filhos, independente de sua fase de desenvolvimento, em tratados e convençôes internacionais e no ordenamento jurídico pátrio, não exercendo, portanto, a parentalidade de forma responsável, devem ser responsabilizados pelos danos morais e materiais causados a essas crianças, independente de sua fase de desenvolvimento.

Nesse sentido Clayton Reis ressalta:

As ofensas à dignidade do nascituro, não importando a sua condição, assinalam sob nossa ótica, uma das mais graves ofensas perpetradas contra quem merece especial proteção da ordem jurídica, particularmente, dos próprios seres humanos, já que não poderemos jamais esquecer, que a nossa própria existência se iniciou através desse processo de desenvolvimento. $^{82}$

Ressalta-se ainda, o exemplo de uma mulher que faz uso de substâncias tóxicas durante a gestação, como álcool, nicotina, crack, maconha, etc ${ }^{83}$. Trata-se de um ato de negligência que poderá implicar em sérios danos para o nascituro. Durante o período gestacional, não é possível outorgar ao concepto danos morais, em decorrência de que não possui capacidade patrimonial, mas nada impede que o juiz determine, por exemplo, o recolhimento obrigatório da mãe em uma clínica de desintoxicação ${ }^{84}$.

Também o abandono durante a gestação pode ensejar a indenização por danos morais ou materiais visto que, este abandono material e emocional da mãe em um momento tão importante, a gestação, traz a ela sentimentos de tristeza, frustração, irritação, insegurança, humilhação e abandono o que causa sérios reflexos no nascituro que tem invadido e lesionado seu patrimônio moral ${ }^{85}$. A família não pode ser vista como um instrumento alheio ao Estado de Direito, local onde suspender-se-á as garantias individuais, motivo que dá o reconhecimento à aplicação de normas gerais da responsabilidade civil de um membro familiar. ${ }^{86}$

Tereza Rodrigues Vieira traz em sua obra o caso de um casal de homossexuais americanas, surdas de nascimento, Duchesneau e McCullough. Elas realizaram seu projeto parental planejando ter filhos com a mesma deficiência e concretizando-o por meio da

82 REIS, 2010, p. 41.

83 De acordo com pesquisa relacionada por Arianne Vilanova Almeida Gaio e Carlyle Popp, a utilização de tabaco durante o período gestacional está relacionada a uma série de complicaçóes, destacando-se o abortamento, malformaçôes fetais (cardíacas e pulmonares), prematuridade, restrição de crescimento intrauterino e recém-nascidos de baixo peso. (Análise da responsabilidade civil da gestante tabagista em relaçâo ao concepto. In: Congresso Nacional do CONPEDI, 20, 2011, Vitória. Anais...Florianópolis: Fundação Boiteux, 2011).

84 SILVA, 2002, p. 371.

85 DALVI, 2008, p. 88.

86 CARDIN, 2012, p. 70. 
doação de gametas de um deficiente auditivo, muito embora fosse possível evitar a deficiência através deste diagnóstico pré-implantacional. ${ }^{87}$

Verificando a situação acima narrada sobre a ótica da responsabilidade civil brasileira, seria possível que futuramente essas crianças ingressassem com uma ação de reparaçáo de danos morais por meio de um representante legal contra suas mães que escolheram que elas viessem a nascer com a deficiência auditiva?

A grande problemática da responsabilidade civil relacionada às técnicas de reprodução humana assistida está no sentido de que, como o embriáo ainda carece de tutela jurídica, não se consegue delinear uma forma possível que os pais poderiam se enquadrar quando se utilizassem da reprodução humana assistida e viessem a provocar um dano ao futuro filho em decorrência disso.

Com relaçáo aos nascituros, dependeria a teoria que fosse adotada para a sua tutela, como por exemplo, os adeptos da teoria concepcionista consideram que a indenização por dano moral é plenamente justificável, uma vez que já seria pessoa e titular de direitos, teria como fundamento tanto a responsabilidade contratual como extracontratual. ${ }^{88}$ Ressaltese que a reparação visa uma compensação pelo mal causado e não um ressarcimento. ${ }^{89}$

Os adeptos da teoria natalista não admite que o nascituro receba uma indenização, visto que não é pessoa, nem sujeito de direitos, ou seja, a falta de personalidade traz a dedução lógica de que esse não poderá ser titular de uma reparação de danos.

Enquanto que os adeptos da teoria da personalidade condicional, a reparação só é passível a partir do nascimento com vida, ou seja, o direito de ser titular desses direitos vai estar condicionado ao seu nascimento com vida, somente assim será considerado pessoa e os danos morais poderão ser cobrados por meio de indenização. Em sentido contrário, se não houver o nascimento com vida, não haveria a possibilidade de reparação de dano, pois o nascituro nunca chegou a ser uma pessoa.

No caso acima descrito a reparação já seria possível, visto que, as crianças já eram nascidas e assim, sujeitos de direito e com personalidade jurídica, mas ainda são situaçóes que o Direito brasileiro não está pronto para enfrentar.

A Ministra Nancy Andrighi adverte que "[...] deve ser superada com uma interpretação técnica e sistemática do Direito aplicado à espécie, que não pode deixar de ocorrer, mesmo ante os intrincados meandros das relaçôes familiares". ${ }^{90}$

87 VIEIRA, 2009, p. 54.

88 CHAVES, 2000, p. 114-117.

89 ALMEIDA, 1992, p. 187.

90 BRASIL. Superior Tribunal de Justiça. REsp n. 1.159.242-SP (2009/0193701-9). Rel. Min. Nancy Andrighi. DJU 10 maio. 2012. Disponível em: http://www.stj.jus.br/webstj/processo/justica/detalhe. asp?numreg=200901937019. Acesso em: 12 jun. 2013. 
Discute-se nas decisões pátrias que não basta ser pai ou mãe, ou ainda prestar alimentos, pois o sustento é apenas uma das atribuiçóes da paternidade, pois é necessário que no exercício da parentalidade haja uma amplitude maior, como o sustento, a guarda e a educação ${ }^{91}$, ou seja, deve-se ter um dever de cuidado, independente da fase de desenvolvimento desse ser.

A ministra ainda destaca que "é possível se se afirmar que tanto pela concepção, quanto pela adoção, os pais assumem obrigações jurídicas em relação à sua prole, que vão além daquelas chamadas necessarium vitae". ${ }^{92} \mathrm{E}$, sobretudo, negar a reparação de danos materiais ou morais causados por um membro da família ao outro, estar-se-ia estimulando a reiteração dessa conduta e alimentando a desintegração familiar. ${ }^{93}$

Por fim, quando os pais não exercem a parentalidade de forma responsável, causando danos morais ou materiais aos filhos, ainda que na fase intrauterina, praticam um ato ilícito, em decorrência de que violem o seu dever de cuidado, além de desrespeitar os direitos personalíssimos de seus filhos. Logo, devem ser responsabilizados civilmente pelas açóes ou omissóes que deram causa.

\section{Conclusões}

O planejamento familiar é de livre decisão do casal e deve ser fundado nos princípios da dignidade humana e da parentalidade responsável sempre, independente de ser em vias naturais e essa responsabilidade ainda cresce quando se trata da utilização das técnicas de reprodução humana assistida.

O princípio da parentalidade responsável consiste na responsabilidade de dar assistência material, moral e intelectual, espiritual e sexual à sua prole, deve ser exercida conscientimente de suas implicaçóes pelos genitores ou aqueles que decidam por realizar o projeto parental.

Apesar do emprego dessas técnicas primariamente ter sido indicada no tratamento a infertilidade, é comum hoje pessoas optarem pelas técnicas de reprodução humana assistida, sendo que o próprio Conselho Federal de Medicina, por meio da Resolução n. 2.013/2013 autorizou seu uso por casais homoafetivos ou por pessoas solteiras.

Outra constatação na utilização dessa técnica está relacionada a falta de tutela do embrião in vitro, que não possui respaldo jurídico e com isso há uma potencialização do

91 ROSA; CARVALHO; FREITAS, 2012, p. 108.

92 BRASIL. Superior Tribunal de Justiça. REsp n. 1.159.242-SP (2009/0193701-9). Rel. Min. Nancy Andrighi. DJU 10 maio. 2012. Disponível em: http://www.stj.jus.br/webstj/processo/ justica/detalhe. asp?numreg=200901937019. Acesso em: 12 jun. 2013.

93 CARDIN, 2012, p. 70. 
mesmo, quando são utilizados em determinados procedimentos que podem provocar sua destruição ou um dano irreversível ao seu normal desenvolvimento, trazendo consequências a sua infância, adolescência e quando adulto.

Alguns exemplos podem ser delineados, como por exemplo, o diagnóstico genético pré-implantacional, no qual é um procedimento admitido pelo Conselho Federal de Medicina, importante para casais que apresentem patologias congênitas, entretanto deve ser limitado no sentido somente de tratar ou prevenir uma doença hereditária, para que não incorra em práticas eugênicas ou a sexagem.

E, também poderá ser realizado para seleção de tipagem do sistema HLA do embrião para seleção de HLA compatíveis com um filho do casal afetado por alguma doença cujo o tratamento efetivo por meio do transplante de células-tronco ou órgáo, o chamado bebê medicamento, que é outra preocupação atual.

A redução embrionária, consiste no procedimento destinado a reduzir o número de fetos nas gestaçóes multifetais, diminuindo as complicaçóes associadas a elas. No Brasil não é permitido pelo Conselho Federal de Medicina, fere diretamente a dignidade e o direito à vida desse embriáo, mas vem sendo aplicada sem controle, não passando de uma prática velada de aborto.

Já a maternidade substitutiva é permitida pelo Conselho Federal de Medicina, por meio da Resolução n. 2.013/2013, regulamentando que fosse realizada quando a mulher tiver algum problema médico que impeça ou contraindique a gestação na doadora genética ou em caso de ser um casal homoafetivo.

Não obstante, a resolução ainda limita o uso da técnica determinando que as doadoras temporárias do útero sejam da mesma família de um dos cônjuges ou companheiros, com parentesco consanguíneo até o quarto grau (primeiro grau - mãe; segundo grau irmã/avó; terceiro grau - tia; quarto grau - prima) e com a idade de no máximo 50 anos. Frise-se ainda que, deverá ser utilizada sem o fim lucrativo.

A Resolução n. 2013/2013 do Conselho Federal de Medicina também regulamentou sobre a possibilidade de realização inseminação post mortem, dispondo que a mulher casada ou em união estável poderia realizá-la, sendo necessário a aprovação do cônjuge ou companheiro para a utilização dessas técnicas e estabelecendo que no momento da criopreservação, os cônjuges ou companheiros devem expressar sua vontade, por escrito, quanto ao destino que será dado aos pré-embrióes criopreservados, em caso de divórcio, doenças graves, ou de falecimento de um deles ou de ambos, e quando desejam doá-los.

O problema referente a esse tema é que retira da criança o direito de conviver com os dois genitores, há que ser considerado o direito indisponível da criança de ter uma família e a convivência com os mesmos. Portanto, a reprodução assistida só deve ser utilizada 
como útimo recurso para realização do projeto parental e não como forma alternativa de reprodução.

Urge ainda, que a legislação regulamente a questão dos embriōes excedentários, visto que, a Resolução n. 2.013/2013 do Conselho Federal de Medicina estabeleceu que os embrióes criopreservados com mais de 5 (cinco) anos poderão ser descartados se essa for a vontade dos pacientes, e náo apenas para pesquisas de células-tronco, conforme previsto na Lei de Biossegurança havia regulamentado.

$\mathrm{Na}$ verdade a melhor saída seria que fosse proibido a produçáo em número excedente, sendo implantado somente o que foi produzido, essa seria a melhor saída e a que mais observaria a dignidade humana desses embriôes.

Deve-se em todo litígio que envolva a reprodução assistida e a proteção do ser em desenvolvimento observar como paradigma norteador de todo procedimento a dignidade da pessoa humana, juntamente com os princípios da parentalidade responsável e do melhor interesse do menor.

Por fim, quando os pais não exercem a parentalidade de forma responsável, causando danos morais ou materiais aos filhos, ainda que na fase intrauterina, praticam um ato ilícito, em decorrência de que violaram um dever de cuidado, além de desrespeitar os direitos personalíssimos de seus filhos e, portanto, devem ser responsabilizados civilmente pelas açôes ou omissốes que deram causa.

\section{Referências}

ALMEIDA, Silmara Juny Abreu Chinellato . Tutela civil do nascituro. São Paulo: Saraiva, 2000.

ALMEIDA, Silmara Juny de Abreu Chinelato e. Direitos da personalidade do nascituro. Revista do Advogado. São Paulo: n. 38, dez. 1992.

ALSINA, José Bustamante. Teoría General de La Responsabilidad Civil. 9. ed. Buenos Aires: Abelardo Perrot, 1997.

AMARAL, Francisco. Direito Civil introdução. 2. ed. Rio de Janeiro: Renovar, 1998.

ANDORNO, Roberto. Bioética y dignidad de la persona. Madrid: Tecnos, 1998.

BARBOZA, Heloisa Helena. Paternidade responsável: o cuidado como dever jurídico. In: PEREIRA, Tânia da Silva; OLIVEIRA, Guilherme de (coord.). Cuidado e responsabilidade. São Paulo: Atlas, 2011.

BARRETO, Wanderlei de Paula. Inovaçôes sobre a personalidade jurídica e os direitos da personalidade no novo Código civil brasileiro. DBJV - Mitteilungen, n. 2, fev. 2004. 
Disponível em: http://www.dbjv.de/dbjv-high/mitteilungen/04-02/DBJV_Mitteilungen_02-2004.pdf. Acesso em: 20 ago. 2011.

BARRETO, Wanderlei de Paula. Por um novo conceito de personalidade jurídica da pessoa natural. Disponível em: http://advocaciabarreto.com.br/index.php?pagina=assuntosacademicos. Acesso em: 21 de out. 2011.

BARROS, Sérgio Rezende. A ideologia do afeto. Revista Brasileira de Direito de Familia. Porto Alegre: Síntese, IBDFAM, v. 4, n. 14, 2000.

BÍSCARO, Beatriz R. Daños derivados de la falta de reconicimiento del hijo. In: GHERSI, Carlos (Coord.). Derecho de Daños: economía, mercado, derechos personalísimos. Buenos Aires: Abelardo Perrot, 1999.

BRASIL, Código Civil brasileiro. Disponível em: Acesso em: http://www.planalto.gov.br / ccivil_03/leis/2002/110406.htm. Acesso em: 29 nov. 2014.

BRASIL. Resolução 2.013/2013 do Conselho Federal de Medicina. Disponível em: http:// portal.cfm. org.br/images PDF/resoluocfm\%202013.2013.pdf. Acesso em: 06 set. 2014.

BRASIL. Superior Tribunal de Justiça. REsp n. 1.159.242-SP (2009/0193701-9). Rel. Min. Nancy Andrighi. DJU 10 maio. 2012. Disponível em: http://www.stj.jus.br/ webstj/processo /justica/detalhe.asp?numreg=200901937019. Acesso em: 12 jun. 2013.

BUENO, Francisco da Silveira. Minidicionário da língua português. 5. ed. São Paulo: Lisa, 1991.

CARDIN, Valéria Silva Galdino. Dano moral no direito de família. São Paulo: Saraiva, 2012.

CARDIN, Valéria Silva Galdino; FROSI, Vitor Eduardo. O afeto como valor jurídico. In: CONPEDI. (org.). XIX Encontro Nacional do CONPEDI. Fortaleza. Florianópolis: Fundação Boiteux, 2010.

CARDIN, Valéria Silva Galdino; ROSA, Letícia Carla Baptista. Da vulnerabilidade do embrião oriundo da reprodução humana assista e da ética da vida. Revista brasileira de direito animal. v. 12, n. 8, p. 181-199, 2013.

CARDIN, Valéria Silva Galdino; ROSA, Letícia Carla Baptista. Do status jurídico do embriāo crioconservado e do princípio da dignidade humana frente a utilização das técnicas de reprodução humana assistida. Disponível em <http://www.publicadireito.com.br/ artigos/?cod=f7efa4f864ae9b88> Acesso em: 17 jun 2014.

CARDIN, Valéria Silva Galdino; WINCKLER, Cristiane Gehlen. Da vulnerabilidade do embrião emergente da reprodução humana assistida. In: SANCHES, Mário Antonio; 
GUBERT, Ida Cristina (org.). Bioética e vulnerabilidades. Curitiba: Champagnat, 2012.

CHAVES, Benedita Inêz Lopes. A tutela jurídica do nascituro. São Paulo: LTr, 2000.

CHUEIRI, Vera Karam de. Fundamentos dos Direitos Constitucionais. Curitiba: IESDE, 2009.

DALVI, Luciano. Curso Avançado de Biodireito. Florianópolis: Conceito Editorial, 2008.

DELGADO, Mário Luiz. Os direitos sucessórios do filho havido por procriaçáo assistida, implantado no útero após a morte de seu pai. Revista Jurídica Consulex, ano VIII, n. 188 de 15 nov. 2004.

DIAS, Maria Berenice. Manual de Direito de Famílias. 5. ed. São Paulo: Revista dos Tribunais, 2009.

DINIZ, Maria Helena. Curso de Direito Civil brasileiro. responsabilidade civil. 16. ed. São Paulo: Saraiva, 2002. v. 7.

DINIZ, Maria Helena. O Estado Atual do Biodireito. 7. ed. São Paulo: Saraiva, 2010. Disponível em: http://www.comciencia.br/noticias/2005/06/celulas_tronco.htm. Acesso em: 12 nov. 2011.

FARIA, Marcos; PETTERSEN, Heverton. Gestação Múltipla. In: DZIK, Artur; PEREIRA, Dirceu Henrique Mendes; CAVAGNA, Mario et. al. (ed.). Tratado de Reprodução Assistida. São Paulo: Segmento Farma, 2010.

FIGO FREITAS, Tiago. A responsabilidade penal pelo diagnóstico pré-natal. Lex Medicinale Revista Portuguesa de Direito da Saúde. Coimbra: Coimbra - Centro de Direito Biomédico, ano 7, n. 13, p. 141-163, 2010.

GAIO, Arianne Vilanova Almeida; POPP, Carlyle. Análise da responsabilidade civil da gestante tabagista em relação ao concepto. Congresso Nacional do CONPEDI, Vitória. Florianópolis: Fundação Boiteux, 2011.

GARCIA, Lenise. Bebê medicamento é uma soluçâo? Disponível em: <http://www.gazetadopovo.com.br/opiniao/conteudo. phtml?id=1230479> Acesso em: 14 set. 2014.

GARCIA, Maria. [et. al]. (Coord.). Biodireito constitucional. Rio de Janeiro: Elsevier, 2010.

GARRAFA, Volnei; PESSINI, Leo. Bioética: poder e injustiça. São Paulo: Loyola, 2003.

GESUALDI, Dora M. Responsabilidad civil: factores objetivos de atribución e relación de causalidad. 2. ed. Buenos Aires: Hammurabi, 2000.

LIMA, Alvino. Culpa e Risco. 2. ed. São Paulo: Revista dos Tribunais, 1988.

MARMITT, Arnaldo. Dano moral. Rio de Janeiro: Aide, 1999. 
MAROJA, Flaviana Estrela; LAINÉ, Agnès. Esperando o Messias: reflexão sobre os bebês para curar um irmão. Disponível em: <http://pepsic.bvsalud.org/scielo.php?scrip$\mathrm{t}=$ sci_arttext\&pid=S1679-44272011000200005> Acesso em: 14 set. 2014.

MEIRELLES, Jussara Maria de Leal; NETO, Nelson Souza. Eficácia do Pacto de São José da Costa Rica na ordem Jurídica Brasileira e a decisão do Supremo Tribunal Federal sobre o uso de embrióes humanos para pesquisa incongruência a indicar alteraçóes. Disponível em: <http://www.publicadireito.com.br/conpedi/manaus/arquivos/Anais/ sao_paulo/2387.pdf> Acesso em: 15 maio 2014.

MICHAELIS. Moderno dicionário da língua portuguesa. São Paulo: Melhoramentos, 1998.

MORAES, Carlos Alexandre. Responsabilidade civil das empresas tabagistas. Curitiba: Juruá, 2008.

NUNES, Pedro. Dicionário de tecnologia jurídica. 12. ed. São Paulo: Freitas Bastos, 1994.

PIRES, Thiago José Teixeira. Princípio da Paternidade Responsável. [2001?]. Disponível em: http://www.apmp.com.br/juridico/artigos/docs/2001/1206_andreluiznogueiradacunha>. Acesso em 02 set. 2007.

REIS, Clayton. A dignidade do nascituro. In: CORREA, Elídia Aparecida de Andrade; GIACOIA Gilberto; CONRADO, Marcelo. Biodireito e dignidade da pessoa humana. Curitiba: Juruá, 2010.

REIS, Clayton. O planejamento familiar: um direito de personalidade do casal. Revista Jurídica Cesumar-Mestrado. v. 8, n. 2, p. 415-435, jul./dez. 2008.

RIBAS, Angela Mara Piekarski. O direito a vida sob uma ótica contemporânea. Disponível em: <http://www.ambito-juridico.com.br/site/index.php?n_link=revista_artigos_ leitura\&artigo_id=2986> Acesso em: 16 jun. 2014.

ROBERTO, Luciana Mendes Pereira. Responsabilidade civil do profissional de saúde \& consentimento informado. 2. ed. Curitiba: Juruá, 2008.

ROMEO CASABONA, Carlos María; QUEIROZ, Juliane Fernandes (Coord.). Biotecnologia e suas implicaçôes ético-jurídicas. Belo Horizonte: Del Rey, 2005.

ROSA, Conrado Paulino da; CARVALHO, Dimas Messias de; FREITAS, Douglas Phillips. Dano moral \& Direito de Família. 2. ed. Belo Horizonte: Del Rey, 2012.

ROSA, Letícia Carla Baptista; CARDIN, Valéria Silva Galdino. Da realização do projeto homoparental por meio da utilização da reprodução humana assistida. XXI Encontro Nacional do CONPEDI, Uberlândia. 2012.

ROSA, Letícia Carla Baptista; CARDIN, Valéria Silva Galdino. Do status jurídico do embriâo crioconservado e do princípio da dignidade da pessoa humana frente a 
utilização das técnicas de reprodução humana assistida. In: MARTEL, Letícia de Campos Velho; SILVA, Monica Neves Aguiar da; ENGELMANN, Wilson (org.). Biodireito. Florianópolis : FUNJAB, 2012.

ROSA, Letícia Carla Baptista; MOCHI, Tatiana Giovanini de Freitas. Da responsabilidade civil decorrente do não exercício da parentalidade responsável na realização do projeto parental. In: OLIVEIRA, José Sebastião de; SANTIAGO, Mariana Ribeiro (Org.). Direito de familia. Florianópolis: FUNJAB, 2012.

SÁ, Maria de Fátima Freire; NAVES, Bruno Torquato de Oliveira. Manual de biodireito. Belo Horizonte: Del Rey, 2009.

SILVA, Américo Luís Martins da. O dano moral e a sua reparaçâo civil. 2. ed. São Paulo: Revista dos Tribunais, 2002.

SILVA, Reinaldo Pereira e. Introdução ao biodireito: investigaçôes político-jurídicas sobre o estatuto da concepção humana. São Paulo: LTr, 2002.

SOUZA, Sérgio Iglesias Nunes de. Responsabilidade civil por danos à personalidade. Barueri: Manole, 2002.

STOCO, Rui. Responsabilidade civil e sua interpretação jurisprudencial. 4. ed. São Paulo: Revista dos Tribunais, 1999.

VASCONCELOS, Cristiane Beuren. A Proteção Jurídica do Ser Humano In Vitro na Era da Biotecnologia. São Paulo: Atlas, 2006.

VENOSA, Sílvio de Salvo. Direito Civil: direito de família. 5. ed. São Paulo: Atlas, 2005, v. 6.

VIEIRA,Tereza Rodrigues. Ensaios de Bioética e Direito. Brasília: Consulex, 2009.

ZATZ, Mayana. Embrióes inviáveis para reprodução, mas fundamentais para pesquisa. Disponível em: <http://veja.abril.com.br/blog/genetica/arquivo/embrioes-inviaveis-para-reproducao-mas-fundamentais-para-pesquisas/> Acesso em: 15 jun 2014. 